\title{
Pharmaceutical Care for Alzheimer Patients
}

\author{
Gustavo Alves Andrade dos Santos ${ }^{1,2 *}$ and Paulo Celso Pardi ${ }^{3}$ \\ ${ }^{1}$ University of São Paulo, USP, School of Medicine of Ribeirão Preto, Brazil \\ ${ }^{2}$ São Leopoldo Mandic, School of Medicine, Araras, Brazil \\ ${ }^{3}$ Lusíada Brasil University Center, Brazil \\ *Corresponding Author: Gustavo Alves Andrade dos Santos, University of São Paulo, \\ USP, School of Medicine of Ribeirão Preto, Brazil. E-mail: gusfarma@hotmail.com
}

Received: October 09, 2021

Published: November 10, 2021

(C) All rights are reserved by Gustavo Alves

Andrade dos Santos and Paulo Celso Pardi.

\section{Abstract}

The emergence of aging-related diseases is becoming a public health problem. In all countries, there is an important increase in dementias, with emphasis on Alzheimer's Disease, the most prevalent among neurodegenerative diseases. Alzheimer's dementia is characterized by impairment of cognitive functions, affecting mental status such as language, memory, attention, skills, as well as behavior and daily activities. Therapy includes pharmacological and non-pharmacological interventions, starting with cholinesterase inhibitor drugs, in the early and intermediate stages of the disease, and drugs with actions based on the non-competitive antagonism of glutamatergic receptors, when the disease is in the intermediate to advanced stages. This work aims to present a pharmaceutical follow-up model aimed at patients with Alzheimer's Disease. The methodology used was initially based on research publications focused on concepts, epidemiological data, diagnoses and treatments for the disease. It was possible to conclude that the role of the pharmacist with the patient and caregivers is of paramount importance for the optimization of pharmacotherapy and quality of life for patients.

Keywords: Pharmaceutical Care; Anticholinesterases; Alzheimer's Disease; Memantine; Rivastigmine; Donepezil; Galantamine; NMethyl D-Aspartate

\section{Introduction}

With the increase in life expectancy generated by technological advances in health, there have been reductions in mortality rates from infectious and chronic diseases, providing the population with a longer survival time, but living longer implies the physiological reduction of organic functions, occurring with greater probability the emergence of chronic and disabling diseases, which can compromise people's autonomy and trigger several of the typical diseases of the elderly, one of them being dementias [1].
We characterize as dementia the set of signs and symptoms demonstrated through language and memory difficulties, behavioral changes and difficulties in daily activities [2].

Being classified as one of the dementias, AD compromises cognitive and intellectual functions, affecting language, personality, memory, visual spatial abilities and cognition. It usually affects elderly people aged 65 years, who, by obtaining an early diagnosis and treatment, can have a good quality of life, delaying the progression of symptoms and, consequently, minimizing possible inconveniences for the family [3]. 
AD was discovered in 1901 by the German physician Alois Alzheimer, who at the time was working as a psychiatrist in a sanatorium, when he received a 51-year-old patient who reported, through her husband, crises of jealousy, behavioral disorders, delusions, memory impairment, among other problems that have been apparent for 11 months. Hospitalized and under the care of the doctor, the patient evolved manifesting loss of recent memory, intensive changes in behavior, inability to perform basic care, disorientation in time and space, feeling of persecution and helplessness [4].

According to the World Health Organization, 35.6 million people suffer from dementia, that is, they have a neurodegenerative syndrome characterized by the deterioration of intellectual abilities that interferes with occupational or social activity. For 2030, a total of about 65.7 million new cases are estimated, which will be tripled in 2050 to 115.4 million, with AD being responsible for $70 \%$ of cases. Only eight countries have developed public treatment programs, which should be a public health priority [5].

In Brazil, the elderly population has been growing every year, but not in proportion to the quality of life, which can be seen from the physiological changes resulting from aging and the State's inability to provide greater care for the elderly [6].

This work aims to carry out a bibliographical survey on the "Pharmaceutical Care" in dementia of the Alzheimer's Disease (AD) type.

\section{Methodology}

The methodology used for the elaboration of the research was the search, in databases, for works related to pharmaceutical care in patients with Alzheimer's disease. We also use the consultation of clinical protocols related to Alzheimer's Disease.

\section{Pathophysiology}

Acetylcholine (ACh) is one of the most important neurotransmitters of the central nervous system (CNS), being secreted from neurons called cholinergics. AD is characterized by primary neurochemical changes in the cholinergic system, causing cholinergic dysfunction and changes in the amount of muscarinic receptors in different brain regions [7]. In the initial phase of the disease, an anatomopathological characteristic is noted for the presence of accumulation of protein B-amyloid, forming senile plaques and neurofibrillary tangles composed of helical filaments and other proteins, being fibrous bands of intracytoplasmic microtubule inclusions. These tangles remain twisted, making it difficult for nerve cells to function and, consequently, synaptic loss and neuronal death. With the progression of the disease, there is loss of neuronal processes and brain atrophy, with a decrease in brain volume and weight, impairment of the hippocampal circuits, the basal forebrain and, consequently, cognition, encompassing the basal nucleus of Meynert and the septal nuclei, which are interconnected the limbic network of memory [8].

As the disease progresses, there is a decrease in the activity of the phospholipase A2 enzyme, causing a reduction in the catabolism of phosphatidylcholine and, consequently, of choline for the synthesis of acetylcholine, increasing the cholinergic deficiency and demarcating the degree of cognitive impairment and severity of $\mathrm{AD}$ [9].

$\mathrm{AD}$ is related to aging, in view of this, some authors have postulated the disease as a premature, rapid and exaggerated aging process, but genetic, environmental and even lifestyle factors and some risk factors also seem to be related [10].

Studies show that increasing age contributes greatly to the prevalence of $\mathrm{AD}$, where brain aging is linked to neuronal death in progressive evolution, decreasing cognitive capacity. Another pointed out and triggering factor, but with studies still not well elucidated, is the higher prevalence in women, as they live on average 5 years longer than men. Other factors mentioned are: history of diabetes, hypertension, obesity, smoking, dyslipidemia, head trauma and genetic factors, where the gene that is related to this disorder is Apoliprotein E4 (apoE4), increasing the risk of developing $\mathrm{AD}$ if the patient inherit the allele of their parents [11]. Due to the chromosomal dysfunction in Down Syndrome, beta-amyloid proteins are generated in excess, causing the accumulation and consequently the senile plaques in the brain, triggering $\mathrm{AD}$ in patients with this syndrome. On the other hand, acting as a form of "protector" in nerve cells, studies, ie, the level of education decrease the chances of developing $\mathrm{AD}$, the greater the intellect, the lower the chance [12].

Several studies emerged after the progressive aging of the world population. According to a report carried out in 2009 , the 
forecast was that in 2010 around 35.6 million people in the world would suffer from AD, and this number would double every 20 years, reaching 65.7 million in 2030 and 115.4 million in 2050. The countries with the highest prevalence of the disease are China, India, the European Union, the United States, Japan, Russia and Indonesia. In European, North American and African studies, AD represents 60 to $70 \%$ of dementia cases [13]. In Brazil, epidemiological data related to $\mathrm{AD}$ and population growth are similar to those in developed countries. According to IBGE data in 1999, the life expectancy of Brazilians was 70 years, increasing to 3.1 years, reaching the age of 73.1 in 2009 . Studies carried out with 1,656 individuals aged over 65 years, quantified a prevalence of $7.10 \%$ of cases of dementia. And new cases of 7.7 person for every 1000 per year. AD represents about $50-60 \%$ of dementia cases, with a higher incidence in people over 65 years of age [14].

\section{Diagnosis}

$\mathrm{AD}$ diagnosis becomes complex, as there is no biological marker of the disease, that is, a specific exam through which the clinician can request and obtain the result and a safe diagnosis. Thus, the most used methodology is performed by exclusion criteria. Some psychiatric pathologies that can compromise cognitive development must be excluded before AD is diagnosed. Some examples include depression, dellirium and other mental disorders associated with dementia, in addition to situations where the patient is experiencing adverse reactions, or has abused any medication, or use of narcotics and alcohol [15].

In Brazil, the criteria used for diagnosis are in accordance with the National Institute of Neurological and Communicative Disorders and Stroke, and the Alzheimer's Disease and Related Disorders Association (NINCDS-ARDA), being diagnosed in three phases: preclinical AD, mild cognitive impairment (CCL) and dementia, where they are classified according to their presented characteristics, or called probable $\mathrm{AD}$, when detected by clinical examination and confirmed with a cognitive test; showing cognitive decline in two or more functions; getting evolved memory deficit and discarding other possible dementia conditions. As for the designation of possible $\mathrm{AD}$, the patient initially presents an unusual development of the disease and other comorbidities may be present, triggering dementia. In defined AD, they present the same criteria for probable $\mathrm{AD}$ and confirmed by biopsy or necropsy [16].
The recommended initial complementary tests are: complete blood count, thyroid function, serum levels of vitamin B12, blood glucose, urea, creatinine, albumin, folic acid, calcium, HIV serology and liver enzymes. Exams such as electroencephalogram (EEG), computed tomography (CT) or preferably magnetic resonance (MR) are mandatory to exclude pathologies related to cerebrovascular disease, subdural hematomas, neoplasms, normal pressure hydrocephalus, vascular dementia and Creutzfeld's disease -Jacob. The examination of the cerebrospinal fluid (CSF) can be used as long as the dementia appears before 65 years of age and there is a suspicion of inflammatory, infectious or prion diseases in the central nervous system. The use of biomarkers related to molecular alterations in AD practically only occurs in research protocols [17]. According to the Clinical Protocol and Therapeutic Guidelines for Alzheimer's Disease 2013 of the Ministry of Health (Brazil), there is a need to perform physical and neurological examinations, assessment of mental status, identifying memory, language and visual-spatial deficits. Included in the diagnostic investigation process, complete history of the patient and family or caregiver, clinical assessment such as the Mini Mental State Examination - MMSE test. There is no evidence so far to recommend SPECT (simple photon emission computed tomography), genetic testing, ApoE genotyping for $\mathrm{AD}$, lumbar puncture (except in the presence of metastatic cancer), suspected central nervous system (CNS) infection, and serum serology for reactive syphilis and hydrocephalus. PET (positron emission tomography), genetic markers for $\mathrm{AD}$, biological markers in $\mathrm{CSF}$ or others for $\mathrm{AD}$, tau protein mutations in patients with frontotemporal dementia, $\mathrm{AD}$ gene mutations in patients with frontotemporal dementia [18].

\section{Pharmaceutical care for patients with alzheimer}

The term Pharmaceutical Care (PA) is defined by the World Health Organization as "a model of pharmaceutical practice, developed in the context of Pharmaceutical Care, which comprises attitudes, ethical values, behaviors, skills, commitments and co-responsibility in disease prevention, health promotion and recovery, in an integrated way to the health team. It is the direct interaction of the pharmacist with the user, aiming at a rational pharmacotherapy and obtaining defined and measurable results, aimed at improving the quality of life" [19]. In developed countries, PA has gradually increased in recent times, focusing on ensuring rational, effective and safe pharmacotherapy, providing health education, 
pharmaceutical care, pharmacotherapeutic monitoring and also evaluating the results and problems related to medications (PRM), minimizing errors and drug interactions [20].

Regarding AD, the treatment starts with the use of a cholinesterase inhibitor, and as the disease progresses, other supporting drugs are introduced to the treatment regimen, such as a non-competitive NMDA-type glutamate receptor antagonist, that is, memantine that is introduced when the disease is in the moderate to severe phase. Serotonergic antidepressants are also associated with treatment, with the function of minimizing behavioral symptoms. Along with guidance on the form of administration and possible adverse effects of drugs, it is important to make the caregiver aware that the goal of treatment is not the total cure of the disease, but the temporary delay of its progression [21].

In the pharmacotherapeutic follow-up form shown in table 1, the pharmacist, as responsible for the guidelines related to medications, should guide the patient towards a better quality of life, through treatment adherence, detecting, preventing, solving adverse reactions (RAMS) and interactions drugs, achieving good pharmacological results [22].

\begin{tabular}{|c|c|c|}
\hline Medicines & Main RAMS & Drug Interactions \\
\hline Donepezil & $\begin{array}{c}\uparrow \text { of gastric secretion, diarrhea, nausea and } \\
\text { vomiting, insomnia, hypertension, ecchymosis, } \\
\text { anorexia, headache. }\end{array}$ & $\begin{array}{l}\text { Ketoconazole, Itraconazole, Erythromycin, } \\
\text { Fluoxetine, Rifampicin, Phenytoin, Carbamazepine, } \\
\text { Alcohol, Ginkgo Biloba. }\end{array}$ \\
\hline Galantamine & $\begin{array}{l}\text { Nausea, vomiting, diarrhea, anorexia, abdominal } \\
\text { pain, dyspepsia, dizziness, headache, depression, } \\
\text { fatigue, insomnia. }\end{array}$ & $\begin{array}{l}\text { Succinylcholine, Cholinergic Agents, } \\
\text { Acetylcholinesterase Inhibitors, Amiodarone, Beta- } \\
\text {-Blockers, Verapamil, NSAIDs. }\end{array}$ \\
\hline Rivastigmine & $\begin{array}{c}\text { Nausea, vomiting, } \uparrow \text { gastric secretion, } \downarrow \text { choli- } \\
\text { nergic activity, seizures, exacerbation of urinary } \\
\text { obstruction. }\end{array}$ & $\begin{array}{c}\text { Acetylcholinesterase Inhibitors, Sodium Channel } \\
\text { Blockers, Food, Beta Blockers, Digoxin, Systemic } \\
\text { Corticosteroids. }\end{array}$ \\
\hline Memantine & $\begin{array}{l}\text { Headache, constipation, dizziness, dyspnea, high } \\
\text { blood pressure, urinary incontinence, increased } \\
\text { libido, drowsiness. }\end{array}$ & $\begin{array}{l}\text { Amantadine, Ketamine, Dextromethorphan, } \\
\text { Ranitidine, Cimetidine, Quinidine, Hydrochlorothia- } \\
\text { zide, Barbiturates, Oral Anticoagulants, Anticonvul- } \\
\text { sants, Neuroleptics. }\end{array}$ \\
\hline Ginkgo Biloba & $\begin{array}{l}\text { Headache, tremors and manic flare-ups, } \\
\text { hypertension. }\end{array}$ & $\begin{array}{c}\text { Acetylsalicylic Acid, Clopidogrel, Warfarin, } \\
\text { Ibuprofen, Naproxen, Phenytoin, Risperidone, } \\
\text { Fluoxetine. }\end{array}$ \\
\hline Selegiline & $\begin{array}{l}\text { Nausea, dizziness, hypotension, dry mouth, } \\
\text { mental confusion, drowsiness. }\end{array}$ & $\begin{array}{l}\text { Paroxetine, Sertraline, Amphetamines, Tricyclic A } \\
\text { ntidepressants, Tramadol, Venlafaxine, Mirtazapine. }\end{array}$ \\
\hline $\begin{array}{l}\text { Vitamin E } \\
\text { Ibuprofen }\end{array}$ & $\begin{array}{l}\text { Nausea, flatulence, diarrhea, muscle weakness, } \\
\text { fatigue, headache. } \\
\text { Edema, skin rash, pruritus, water retention, } \\
\text { heartburn, epigastric pain, constipation, } \\
\text { diarrhea. }\end{array}$ & $\begin{array}{l}\text { Aluminum Hydroxide, Anticoagulants Derived from } \\
\text { Coumarin or Warfarin. } \\
\text { Cyclosporin, Digoxin, Lithium, Methotrexate, ACE } \\
\text { Inhibitors, Phenytoin, Fluoxetine, Losartan, } \\
\text { Glimepiride, Warfarin, Montelukast. }\end{array}$ \\
\hline
\end{tabular}

Table 1: Pharmacotherapeutic form for patients with AD [23-25].

Source: Article Authors

Being aware that the pharmacist is the last professional with whom the patient will have contact before the start of therapy, and that many times numerous questions regarding the dosage, indication, side effects, among other questions, for some reason 
were not resolved by the prescriber, clear and accurate information will be extremely important to guarantee the prevention of adverse events, preventing, detecting and solving them in the best possible way, enabling a better quality of life for the patient and adherence to treatment. In the pharmaceutical guidelines for the patient, represented in table 2 , some recommendations related to the treatment are described, which will provide the patient with more safety, comfort and adherence [26].

\begin{tabular}{|c|c|}
\hline Medicine & Guidance provided \\
\hline Donepezil & $\begin{array}{l}\text { Administration should be carried out with or } \\
\text { without food, before bedtime. }\end{array}$ \\
\hline $\begin{array}{l}\text { Galanta- } \\
\text { mine }\end{array}$ & $\begin{array}{l}\text { Guide the administration with food, as this way } \\
\text { nausea is reduced. If therapy is stopped for } 3 \\
\text { days or more, restart with the lowest dose. }\end{array}$ \\
\hline $\begin{array}{l}\text { Rivastig- } \\
\text { mine }\end{array}$ & $\begin{array}{l}\text { Adverse reactions usually disappear within } 1 \text { to } \\
3 \text { weeks. Due to delayed absorption, it should } \\
\text { be administered away from meals. The use of } \\
\text { drugs with cholinergic action is not indicated. } \\
\text { Transdermal administration is a single daily dose, } \\
\text { which must be removed before placing the next } \\
\text { patch, should be applied on the back, chest or } \\
\text { upper arms, if redness, swelling, itching or local } \\
\text { irritation occurs, remove the patch and report the } \\
\text { prescriber. }\end{array}$ \\
\hline Mem & $\begin{array}{l}\text { It can be administered near or far from meals, } \\
\text { preferably at the same time every day. If you } \\
\text { make changes in the diet, the prescriber should } \\
\text { be notified due to possible changes in urinary pH, } \\
\text { influencing the clearance. }\end{array}$ \\
\hline $\begin{array}{l}\text { Ginkgo } \\
\text { Biloba }\end{array}$ & $\begin{array}{l}\text { Must be administered before meals. Avoid exces- } \\
\text { sive consumption of foods containing tyramine } \\
\text { due to the possibility of hypertension. }\end{array}$ \\
\hline Ibuprofen & $\begin{array}{l}\text { Administer with food in order to reduce the } \\
\text { aggregation of the gastrointestinal tract. }\end{array}$ \\
\hline Selegilina & $\begin{array}{l}\text { Avoid concomitant use with foods rich in tyrami- } \\
\text { ne, for example: wines, aged or matured cheeses, } \\
\text { dried or cured meats, due to a sudden increase in } \\
\text { blood pressure. }\end{array}$ \\
\hline Vitamin E & $\begin{array}{l}\text { Ingest before or after meals, do not exceed the } \\
\text { daily dose recommended by the prescriber. The } \\
\text { adjuvant use of vitamin } C \text { helps in better absorp- } \\
\text { tion. }\end{array}$ \\
\hline
\end{tabular}

Table 2: Pharmaceutical guidelines form for patients with Alzheimer's [27-29].

Source: Article authors
For effective pharmaceutical care, a pharmacist's approach is necessary when doubts or questions are presented regarding the use of medications, with the purpose of identifying whether there are existing chronic diseases and which medications are used. It should mention possible adverse drug reactions (ADR) presented during the interview, identify possible self-medication and whether the prescriber knows all the drugs used by the patient [30].

The pharmacist should conduct the interview with the patient, family member or caregiver, seeking to maintain the closest possible follow-up, providing a calm dialogue, listening to their complaints and resolving their doubts, with special attention to the caregiver or family member, considering that they may report more accurately and precisely your doubts, adverse reactions that occurred during the treatment, with this the pharmacist can reinforce the prescriber's guidance on the progression of the disease, and treatment evolution, regarding the best pharmacotherapeutic follow-up and reduction of the incidence of ADR [31].

Non-pharmacological interventions also provide the patient and family with an impact on quality of life. The Pharmacist, aware of the special needs of the AD patient, can intervene advising on the development of an organized routine for the patient's daily life, suggest adaptations in the environment according to existing needs, guide the family member to encourage appropriate behavior, indicate activities occupational, or that will provide well-being, such as music therapy that provides, in most cases, improvement of agitation [32].

\section{Discussion}

Studies have shown that the provision of pharmaceutical care brings benefits to the patient's health and to the health promotion process, because after clarification and guidance, there is better adherence to pharmacological treatment, according to Zanghelini., et al. (2013), a group of patients with uncontrolled severe asthma, showed significant improvement in asthma, and resolution of MRPs after pharmacotherapeutic follow-up, individualized verbal guidance, information on the rational use of medications, and pharmaceutical interventions [33].

For Partara., et al. (2010), pharmaceutical interventions with educational measures, guidelines for a better pharmacotherapeutic follow-up, and health promotion, benefits the patient's health, improving their quality of life, and treatment adherence, these 
measures can be extended to the family companion, caregiver, prescribing physician and health professionals [34].

\section{Conclusion}

Interventions performed in pharmacotherapy aim at adherence to treatment and improvement in the quality of life of patients with $\mathrm{AD}$, providing guidance as to the proper form and time to administer the doses. In addition, they clarify doubts that arise during the course of the disease, which provides the patient with an adequate understanding and use of the medication, for a safe and effective treatment with a significant reduction in ADRs. Through the research carried out in this work, we concluded that the Pharmacist can contribute and play a relevant role with $\mathrm{AD}$ patients, through their professional attributions and competences, promoting health and rational use of medicines.

\section{Bibliography}

1. Burla C., et al. "Panorama prospectivo das demências no Brasil: Um Enfoque Demográfico Portugal”. Ciência and Saúde 18.10 (2012): 2949-2956.

2. Dias CL., et al. "Perfil Clínico e Autonômico de Pacientes com Doença de Alzheimer e Demência Mista”. Revista da Associação Médica Brasileira 59 (2013): 435-441.

3. Silva HL. "Doença de Alzheimer: Epidemiologia e Alternativas Diagnósticas” (2012).

4. Vono, Zulmira Elisa. O bem no Mal de Alzheimer/Zulmira Elisa Vono. São Paulo: Editora SENAC São Paulo, 2009.

5. Prince M., et al. "The global prevalence of dementia: a systematic review and metaanalysis". Alzheimers Dement 9.1 (2013):63-75. doi: 10.1016/j.jalz.2012.11.007

6. Meireles EA. "Alterações Neurológicas Fisiológicas ao Envelhecimento Afetam o Sistema Mantenedor do Equilíbrio". Goiás, Revista Neurociência 18.1 (2010): 103-108.

7. Ventura LMA. "Sistema Colinérgico: Revisando Receptores, Regulação e a Relação com a Doença de Alzheimer, Esquizofrenia, Epilepsia e Tabagismo Rio de Janeiro". Revista de Psiquiatria Clínica 37.2 (2010).
8. Cavalcante JLS and Evangelhardt E. "Aspectos da Fisiopatologia da Doença de Alzheimer Esporádica". Revista Brasileira de Neurologia 48.4 (2012).

9. Sereniki A and Vital FSA M. "A Doença de Alzheimer: Aspectos Fisiológicos e Farmacológicos". Revista de Psiquiatria 30.1 (2008).

10. Mayeux R and Stern Y. "Epidemiology Of Alzheimer Disease". Cold Spring Harbor Perspectives in Medicine 2.8 (2012).

11. Carretta MB and Scherer S. "Perspectivas Atuais na Prevenção da Doença de Alzheimer". Revista Estud. Interdisci. Envellhec 17.1 (2012): 37-57.

12. Arró OS and Blanco LR. "Prevalencia Del Síndrome Demencial Y La Enfermedad de Alzheimer en Pacientes Del Policlínico "Pedro Fonseca", Ver". Revista Cubana De Medicina General Integral 28.4 (2012).

13. Sánchez RC., et al. "Epidemiologia y Carga de La Enfermedad de Alzheimer". Acta Neurológica Colombiana 26.3 (2010): 8894.

14. Gonçalves GAE and Carmo SJ. "Diagnóstico da Doença de Alzheimer na População Brasileira: Um Levantamento Bibliográfico". Revista Psicologia e Saúde 4.2 (2012).

15. Nitrini Ricardo. "Diagnóstico de doença de Alzheimer no Brasil" 63.3 (2005): 713-719.

16. Frota., et al. Criteria for the diagnosis of Alzheimer's disease: Recommendations of the Scientific Department of Cognitive Neurology and Aging of the Brazilian Academy of Neurology (2011).

17. Caramelli P., et al. "Diagnóstico de Doença de Alzheimer no Brasil". Dementia e Neuropsychologia 5.1 (2011): 11-20.

18. Brasil. Ministério da Saúde.Secretaria de Atenção a Saúde. Protocolo Clínico e Diretrizes Terapêuticas da Doença de Alzheimer. Available in https://bvsms.saude.gov.br/bvs/ saudelegis/sas/2013/prt1298_21_11_2013.html.

19. Consenso Brasileiro de Atenção Farmacêutica. Atenção Farmacêutica no Brasil: Trilhando Caminhos. Brasília: Organização Pan - Americana da Saúde (2002): 24. 
20. Meneses LLA and Sá BLM. Atenção farmacêutica ao idoso: fundamentos e propostas (2010).

21. Forlenza V O. "Tratamento Farmacológico da Doença de Alzheimer". Revista de Psiquiatria Clinica 32.3 (2005): 137-148.

22. Pinheiro SJ., et al. "Interações Medicamentosas e a Farmacoterapia de Pacientes Geriátricos com Síndrome Demenciais". Revista Brasileira Geriatria Gerontologia 16.2 (2013).

23. PharmD MPLFC., et al. Medicamentos Lexi-Comp Manole, $1^{\text {a }}$ edição. São Paulo, Manole (2009): 468-469-666-738-739740-874-1185-1186-1205-1206.

24. Fuchs DF and Wannmacher L. Farmacologia Clínica, 4⿳a edição. Rio de Janeiro, Guanabara Koogan Ltda, (2010): 416-418-419810-811-1142-1143.

25. Nicoletti AM., et al. “. Principais Interações no Uso de Medicamentos Fitoterápicos". Infarma 19.1/2 (2007): 32-40.

26. Botasso MR., et al. "Reação Adversa Medicamentosa em Idosos". RBCEH 8.2 (2011): 285-297.

27. PharmD MPLFC., et al. Medicamentos Lexi-Comp Manole, $1^{\mathrm{a}}$ edição. São Paulo, Manole (2009): 468-469-666-738-739740-874-1185-1186-1205-1206.

28. Fuchs DF and Wannmacher L. Farmacologia Clínica, 4aㅗ edição. Rio de Janeiro, Guanabara Koogan Ltda, (2010): 416-418-419810-811-1142-1143.

29. Acetato de racealfatocoferol 16 (2014): $30 \mathrm{~h}$.

30. Sabino DB., et al. "Atenção Farmacêutica para Pacientes Portadores de Doença de Alzheimer". Revista da Rede de Ensino Diálogos and Ciências (2008).

31. Pereira LRL and Freitas O. "A Evolução d atenção Farmacêutica e a Perspectiva para o Brasil". Revista Brasileira de Ciência Farmacêuticas 44.4 (2008).

32. Lopes LC., et al. "Doença de Alzheimer: Prevenção e Tratamento". Diretrizes Clínicas na Saúde Suplementar (2011): 1-20.

33. Zanghelini F., et al. "Impacto da Atenção Farmacêutica na Função Pulmonar de Pacientes com Asma Grave". Revista de Ciências Farmacêuticas Básicas e Aplicadas 34.3 (2013).
34. Partara AK., et al. "Atuação do Farmacêutico na Promoção e Restauração da Saúde de Pacientes Idosos que Fazem Uso de Polimedicação". Revista Ipatac 3.2 (2010): 5-15.

35. Wishah RA., et al. "Impact of Pharmaceutical Care Interventions on Glycemic Control and other Health-Related Clinical Outcomes in Patients with Type 2 Diabetes: Randomized Controlled Trial". Diabetes and Metabolic Syndrome: Clinical Research and Reviews (2014).

36. Ambiel ISS and Mastroianni PC. "Resultados da Atenção Farmacêutica no Brasil: Uma Revisão". Revista Ciências Farmacêuticas Básicas e Aplicada 34.4 (2013): 469-474.

Volume 5 Issue 12 December 2021

(C) All rights are reserved by Gustavo Alves Andrade dos Santos and Paulo Celso Pardi. 